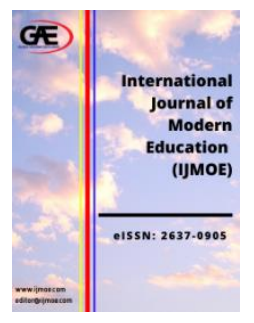

INTERNATIONAL JOURNAL OF

MODERN EDUCATION

(IJMOE)

www.ijmoe.com

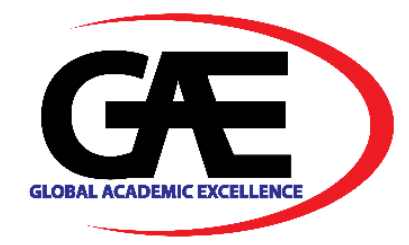

\title{
THE TOOL FOR SCHOOL LEADERS IN MEASURING CLIMATE FACTORS FOR BETTER EDUCATIONAL IMPROVEMENT
}

\author{
Bridget Lim Suk Han ${ }^{1 *}$ \\ 1 Institut Aminuddin Baki Cawangan Sabah \\ Email: bridgetlim@iab.edu.my \\ Corresponding Author
}

\section{Article Info:}

Article history:

Received date:01.09.2020

Revised date: 08.09.2020

Accepted date: 13.09.2020

Published date: 15.09.2020

\section{To cite this document:}

Lim, B. S. H. (2020). The Tool for School Leaders in Measuring Climate Factors for Better Educational Improvement. International Journal of Modern Education, 2(6), 50-61.

DOI: 10.35631/IJMOE.26005

\begin{abstract}
:
Different schools that are nestled in different locality possess different climate factors. For this paper, it emphasizes mainly on how climate factors of a school influence pupils and teachers in the teaching and learning processes in the English language. The case site is a low performing rural primary school in a bucolic setting in the state of Sabah which is $130 \mathrm{~km}$ away from the nearest urban centre. The main purpose of this paper is to delineate the building of an instrument as a tool for school leaders to start analysing climate factors for better educational improvement. There are four general concepts depicted under the climate factors - physical environment, social relationship/system, orderliness, and expectations on student outcomes (and teacher behaviours). To ensure more holistic measurement of these indicators, five measurement dimensions - frequency, focus, stage, differentiation, and quality are adopted. Sources of data are from various data collection methods namely peripheral observation, classroom observation, classroom participation, formal interview, conversational interview, focus group interview as well as documents. Multiple sources of data ascertain triangulation and better trustworthiness of the data to facilitate the building of a comprehensive instrument with wideranging constructs. This instrument can be used as a self-evaluation guide for school leaders to further understand the weaknesses as well as strengths of their schools. Through the synthesis of the data collected using this instrument, it has facilitated clear discernment of the capacities for the case school underinvestigated and how the roles of financial, human, time, and programme capacity affect the pupils' performance in the English Language.
\end{abstract}

\section{Keywords:}

Climate Factors, Physical Environment, Social Relationship/System, Orderliness and Expectations on Student Outcomes (And Teacher Behaviours) 


\section{Introduction}

Before any improvement programmes can be implemented, comprehensive data are required as prerequisite to plan more relevant programmes. Based on the data gathered through a case study of a low performing rural primary school in Sabah, pupils' performance could be affected interdependently by the climate and effectiveness factors within the school as well as classroom.

The interrelationship between these factors would be useful in finding 'why' such causal relations happened so that various steps on school improvement could be advocated. For this paper, it concentrates mainly on building an instrument that can be served as a tool to gauge the existing capacity and capability of the schools focussing on the climate factors that influence in the teaching and learning processes of the English language of this case school. Such strategy if a way for educational leaders to tailor appropriate remedies to better tackle educational challenges of their respective organization.

\section{The Issue and Objective of This Paper}

Different schools which are nestled in different locality possess different climate factors. Climate factors for both school and classroom levels should not only support each other but also the effectiveness factors for both the levels in order to augment pupils' performance. There are our general concepts depicted under each climate factors - physical environment, social relationship/system, orderliness and expectations on student outcomes (and teacher behaviours). These four elements are compatible to physical, social, affective/emotional and academic environment respectively of a school and classroom. According to Tableman (2004), these four aspects of environment "provide the preconditions necessary for teaching and learning to take place" (p. 2) in a school and classroom.

English is basically one of the subjects taught in primary schools. As with other subjects, the teaching and learning of English in primary schools is carried out within the context of a school and classroom. Hence, by researching on the climate settings, it helps to put to light what the factors and the relationship of these factors affect the teaching and learning processes of English among the pupils.

According to Teddlie (1994), the areas of school effectiveness and teacher effectiveness in classroom were examined separately where the teacher effectiveness studies were concentrated on the processes occurred within the classroom to the exclusion of school level factors. Hence, a multilevel plan is needed to help illustrate the interrelationship between the school and teacher/classroom effectiveness on English language teaching and learning.

This multilevel School Effectiveness Plan has been introduced during various national and international conferences. This adapted plan is attached in Figure 1. The adoption of the plan for the case school is due to the fact that the preliminary data collected on the causal relationships between the climate factors and the teaching and learning of the English language from the case school is in congruence with aspects indicated in the adapted plan. Hence, this adapted plan can lay the fundamental groundwork for more in-depth investigation in building an appropriate tool for self-assessment and self-improvement purposes. 


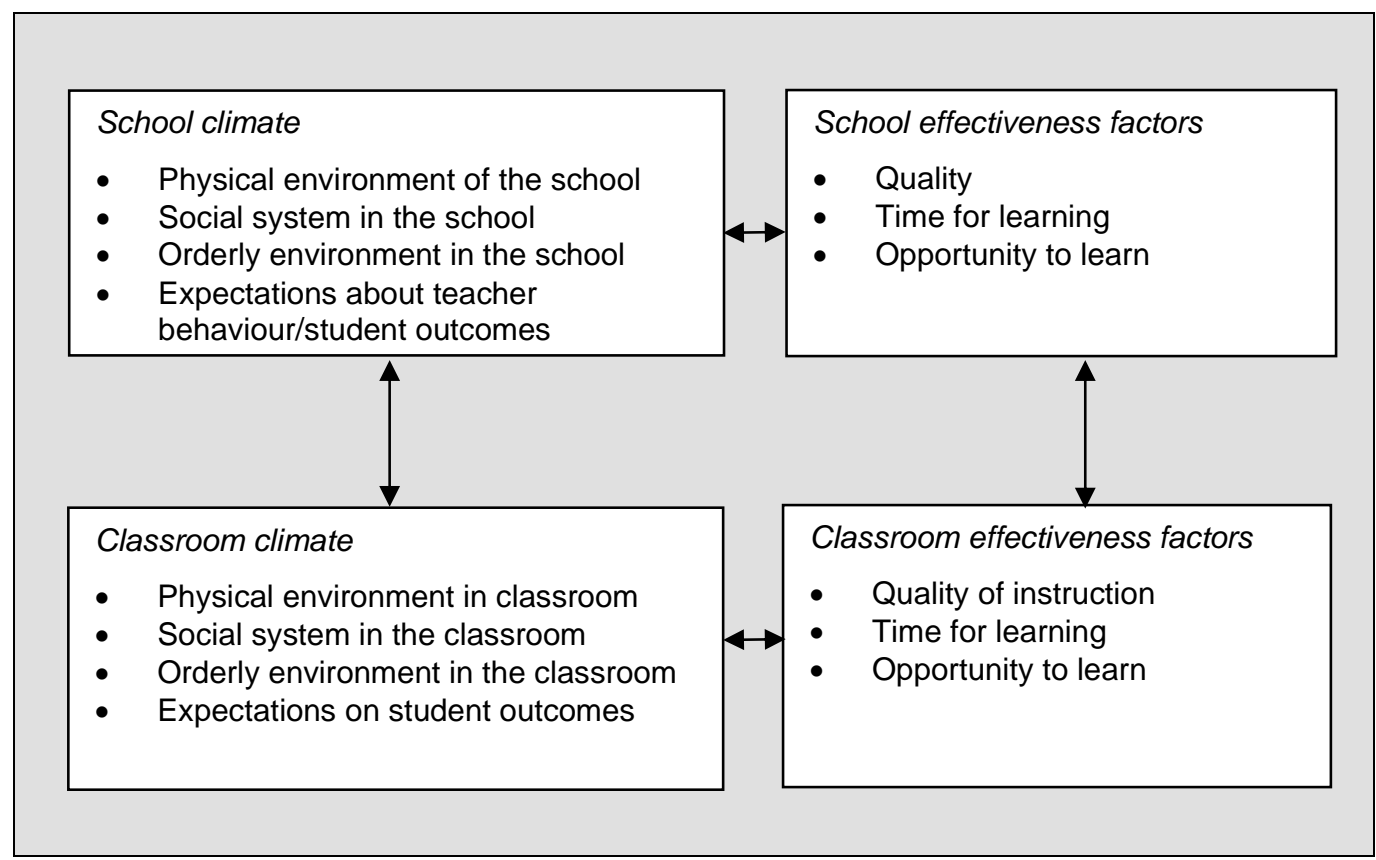

Figure 1: The Multilevel School Effectiveness Plan

Source: Adapted from "The role of School and Classroom Climate in Elementary School Learning Environment" by B. P. M. Creemers, \& G. J. Reezigt, 1999, in H. J. Freiberg (ed.), School Climate: Measuring, Improving and Sustaining Healthy Learning Environments, p. 31.

In point of fact, there were a lot of school and educational effectiveness researches done based on this model in different countries namely the Netherlands, Denmark, Norway and Sweden because it was one of the most influential theoretical constructs in the field. However, most of these studies were conducted quantitatively where questionnaires were administered. Questionnaires are normally prepared with predetermined factors. Since each school is unique and different in all aspects, the items prescribed in the questionnaires may not be fully reflecting the attributes especially those significant to a specific educational institution. For example, according to Kyriakides, Campbell, and Gagatsis, A. (2000), quality of teaching (which is deemed essential in current primary teaching) did not have statistically significant effect on pupils when they were using the Creemers' model to derive data from 30 schools, 56 classes and 1,051 pupils on pupils' achievement in Mathematics. This, in accordance to Creemers (1994), was largely due to the complexity in primary school teaching. Therefore, conducting a case study using this multilevel model and gathering qualitative data using especially through observations and interviews as initiated in this study was truly enlightening and meaningful to contribute to the research knowledge base on educational effectiveness. Such claim was too put forward by Fitz-Gibbon (as cited in Kyriakides et al., 2000).

\section{Review of Literature - School and Classroom Climate Factors}

As disclosed by Creemers and Reezigt (1999), "school and classroom are more than the sum of their effectiveness factors" (p. 33) and thus the inclusion of the climate factors completes the picture of school effectiveness. Classroom climate is described as the stepchild of psychological and classroom research (Creemers \& Reegizt, 1999), whereas school climate research is dubbed as the stepchild of organizational climate research and school effects research (Anderson, 1982). Hence, the school and classroom climate factors stand as separate categories in the conceptual framework of this study as they are considered the managerial techniques in creating optimal conditions for learning and instruction but insufficient to Copyright (C) GLOBAL ACADEMIC EXCELLENCE (M) SDN BHD - All rights reserved 
produce good pupil results (Creemers, 1994). Through the meta-analysis of main findings on TERs (Teacher Education Researches) and EERs (Educational Effectiveness Researches), there was a whole long list of school variables which were seen to be related to pupil outcome. As my study hypothesized that the school level factors were conditional to the classroom level factors, school climate variables that were sustaining and facilitating these classroom climate variables relevant in influencing pupil achievement were taken into consideration.

In relation to the multilevel School Effectiveness Plan as depicted in Figure 1, both school and classroom climate factors look upon the 4 similar key concepts of physical environment, social system, orderly environment and expectations about teacher behaviour and student outcomes. These four concepts show the essential establishment of four environments - physical, social, affective and academic to institute a climate which encouraged better student academic performance.

Through the results of meta-analysis by Kyriakides and Creemers (2008), the five variables that were crucial for teachers in creating a better learning environment in the classroom include:

(i) teacher-student interaction,

(ii) student-student interaction,

(iii) students' treatment by the teacher,

(iv) competition between students, and

(v) classroom disorder.

Whereas the five variables that surfaced through meta-analysis of EERs by Kyriakides, Creemers, Antoniou and Dementriou (2010, p. 813) on effective school climate involved,

(i) student behaviour outside the classroom, (related to the safe school physical environment),

(ii) collaboration and interaction between teachers,

(iii) partnership policy (i.e., relations of school with community, parents, and advisors),

(iv) provision of sufficient learning resources to students and teachers, and

(v) values in favour of learning.

\section{Research Methods Involved in Building the Instrument}

As a matter of fact, this paper is emancipated from a larger ethnographic fieldwork case study conducted at one of the lows performing primary schools in Sabah. This ethnographic case study opens an opportunity for the researcher to submerge in the "lived" experience and learn the life of a school community which is under performing and away from the hustle and bustle of the city life.

The process of investigating a school in this nature is truly challenging but fulfilling. It gives the researcher who is an outsider a sense of belonging and concern for the happenings at the school. Henceforth, by using this platform to formulate a measurement tool specially tailored for the school will be truly meaningful.

\section{The Case School}

The case site is a low performing rural primary school in a bucolic setting in the state Sabah which is $130 \mathrm{~km}$ away from a nearest urban centre. The case school is located at a remote area where the projection of the foot of Mount Kinabalu is extended to. 
Volume 2 Issue 6 (September 2020) PP. 50-61 DOI: 10.35631/IJMOE.26005

The case school is a Low Enrolment School. Low Enrolment School (LES) or "Sekolah Kurang Murid (SKM)" is defined as a school with less than 150 pupils. Recognising that public education is the only form of education available to these rustic folks even though it is costly to build schools especially if the rate of use is low, the government still build for them to ensure that all our children have the equal opportunity to receive quality education (Lim, 2018).

\section{Research Matrix}

A research matrix is basically an attempt to put the essential ingredients of the study in perspective to enable a researcher to handle the case holistically. The researcher proposes to use a research matrix as depicted in Table 1, is essential in putting the objectives and guiding concepts together to determine the following:

(i) sources of data

(ii) techniques in obtaining the data

(iii) techniques in analysing the data

Table 1: Research Matrix on Sources and Techniques in Obtaining and Analysing Data

No. Guiding $\quad$ Source of Data $\quad \begin{gathered}\text { Technique of } \\ \text { Gathering }\end{gathered} \quad \begin{gathered}\text { Technique of } \\ \text { Analysis }\end{gathered}$

\section{School Climate Factors}

1 Physical environment a. School setting

b. Teachers

c. Support staff

d. District language

Officer
a. Facility check
b. Observation
c. Documents
d. Interviews

a. Head Teacher

Social
relationship

b. Teachers

c. Pupils

d. Parents
a. Observation
b. Focus Interviews
c. Related Documents
a. Check on facility used
b. Data reduction
c. Documents analysis
d. Interpretative analysis
a. Data reduction
b. Document analysis
c. Interpretative analysis

a. Data reduction

b. Document analysis

c. Interpretative analysis

$\begin{array}{ll}\text { Expectation of } & \text { a. Head Teacher } \\ \text { teacher } & \text { b. Teachers } \\ \text { behaviour \& } & \text { c. Pupils } \\ \text { student } & \\ \text { outcomes } & \end{array}$

a. Data reduction

b. Document analysis

c. Interpretative analysis 
Table 1: Research Matrix on Sources and Techniques in Obtaining and Analysing Data (Continued)

\begin{tabular}{|c|c|c|c|c|}
\hline No. & $\begin{array}{l}\text { Guiding } \\
\text { Concepts }\end{array}$ & Source of Data & $\begin{array}{l}\text { Technique of } \\
\text { Gathering }\end{array}$ & $\begin{array}{c}\text { Technique of } \\
\text { Analysis }\end{array}$ \\
\hline \multicolumn{5}{|c|}{ Classroom Climate Factors } \\
\hline 1 & $\begin{array}{l}\text { Physical } \\
\text { environment }\end{array}$ & $\begin{array}{l}\text { a. Classroom } \\
\text { setting } \\
\text { b. Teachers } \\
\text { c. Pupils }\end{array}$ & $\begin{array}{l}\text { a. Facility check } \\
\text { b. Observation } \\
\text { c. Documents } \\
\text { d. Interviews }\end{array}$ & $\begin{array}{l}\text { a. Check on facility } \\
\text { used } \\
\text { b. Data reduction } \\
\text { c. Documents analysis } \\
\text { d. Interpretative } \\
\text { analysis }\end{array}$ \\
\hline 2 & $\begin{array}{l}\text { Social } \\
\text { relationship }\end{array}$ & $\begin{array}{l}\text { a. Teachers } \\
\text { b. Pupils }\end{array}$ & $\begin{array}{l}\text { a. Observation } \\
\text { b. Focus } \\
\text { Interviews } \\
\text { c. Related } \\
\text { Documents }\end{array}$ & $\begin{array}{l}\text { a. Data reduction } \\
\text { b. Document analysis } \\
\text { c. Interpretative } \\
\text { analysis }\end{array}$ \\
\hline 3 & Orderliness & $\begin{array}{l}\text { a. Classroom } \\
\text { setting } \\
\text { b. Teachers } \\
\text { c. Pupils }\end{array}$ & $\begin{array}{l}\text { a. Observation } \\
\text { b. Documents } \\
\text { c. Interviews }\end{array}$ & $\begin{array}{l}\text { a. Data reduction } \\
\text { b. Document analysis } \\
\text { c. Interpretative } \\
\text { analysis }\end{array}$ \\
\hline 4 & $\begin{array}{l}\text { Expectation on } \\
\text { student } \\
\text { outcomes }\end{array}$ & $\begin{array}{l}\text { a. Teachers } \\
\text { b. Pupils }\end{array}$ & $\begin{array}{l}\text { a. Observation } \\
\text { b. Documents } \\
\text { c. Interviews }\end{array}$ & $\begin{array}{l}\text { a. Data reduction } \\
\text { b. Document analysis } \\
\text { c. Interpretative } \\
\text { analysis }\end{array}$ \\
\hline
\end{tabular}

Using a research matrix also helps in ensuring multiple sources of data for triangulation, which means "comparing and cross-checking data collected through observation at different times or different places, or interview data collected from people with different perspectives or from follow-up interview with the same people" (Merriam, 2009, p. 216). This surely increases the level of credibility of the data collected.

The data collection process is conducted until the data reach the saturation point. In accordance to Gay, Mills, and Airasian (2009), when the data reach saturation point, it is when a researcher "begins to hear the same thoughts, perspectives and responses from most or all of the participants" and no "additional participants are needed for that particular topic or issue" ( $\mathrm{p}$. 137). Then the researcher is certain that adequate engagement has been invested in the data collection and rich data of the case school has been well documented. 
Table 2: Types of Data

\begin{tabular}{|c|c|c|c|}
\hline No. & Source of Data Gathering & $\begin{array}{l}\text { Medium of Data } \\
\text { Gathering }\end{array}$ & Types of Data \\
\hline 1 & Peripheral observation & Note-taking & - Fieldwork journals \\
\hline 2 & Classroom observation & Video-recording & - Transcriptions \\
\hline 3 & Classroom participation & & - Photographs \\
\hline 4 & Formal interview & Note-taking & - Fieldwork journals \\
\hline 5 & Conversational interview & Audio-recording & - Transcriptions \\
\hline 6 & Focus group interview & & - Photographs \\
\hline 7 & Document Analysis & Documents & $\begin{array}{l}\text { - Photocopied materials } \\
\text { - Photographs }\end{array}$ \\
\hline
\end{tabular}

\section{Data Analysis - Building the Instrument}

From Table 2 above, most of the data gathered is ready for subsequent analysis except videoand audio-recordings. These two types of data make up a huge bulk of the data. Hence, transcribing and making them ready for analysis is extremely crucial.

For the video-recordings, the researcher adopts the "whole-to-part" or "inductive approach" when transcribing my data. This approach, according to Erikson (2006), is preferred in context analysis, ethnographic analysis and conversational analysis (p. 183). With the availability of the pre-determined variables from the guiding concepts, only parts of the video-recordings which containing the phenomena of interest are replayed and repeated in order to get a detailed transcription of them.

Nevertheless, before such micro-analysis and transcription are carried out, each entire videorecording is viewed and reviewed for the researcher to get acquainted and familiarised with the setting where the video footage is set so that the selective transcription could be made more contextualised. Such selective analysis of data assisted the researcher in carrying out more systematic comparison and triangulation of data across multiple sources of data to determine typicality or even atypicality of issues (Erikson, 2006, p. 185) for the subsequent data interpretative analysis so that a more comprehensive instrument relevant to the case school can be formulated.

As for interview data, there was no single agreed-on standard for preparing transcripts for audio-recordings and so the researcher as the primary researcher of this study needed to make systematic decisions about the transcription conventions (Brenner, 2006, p. 365). Since the interview protocol is basically based on the variables in relation to the guiding concepts, a global approach is adopted in the transcribing process where the researcher practically transcribes everything as appears in the interview data.

With my guiding concepts in perspective as illustrated in Figure 1, more focused and selective coding are done on the data gathered. According to Hesse-Biber and Leavy (2006), focused coding which is an important step in data reduction "allows for the building and clarifying of concepts" especially after comparing "each piece of data with every other piece" (p. 352). 


\section{Research Outcome - The Instrument}

The case of this study is investigated thoroughly on all the aspects namely physical, human, interactional and programme settings are taken into consideration. All activities, behaviours and reactions of the informants of the case especially head teacher, teachers, and pupils are properly documented. With the detailed scrutiny and analysis of the data collected through the identification of polas, patterns, issues and even dilemmas, the researcher is able to extract the very concepts and dimensions unique to the case particularly on the influence school climate in the teaching and learning of the English language.

The data collected indicates the importance of scrutinising each piece of evidence from different perspectives. A piece of data may look significant in the eyes of the leaders but irrelevant in the perspective of the pupils. Hence, the saturated data has provided a pool of evidence that can be graded in different dimensions.

The very achievement bestowed on the researcher is the ability to sort the evidence according to the dimensions which resemble the five measurement dimensions namely frequency, focus, stage, differentiation and quality, which are popularized by Creemers and Kyriakides (2008). This adds a great value to the instrument as the holistic and objective measurement criteria help to elevate the validity of subjective data to be gathered by the instrument.

The various aspects of each of the guiding concepts for the climate factors teased out of the data, and the 5 measurement dimensions have been integrated to formulate a tool as shown in Table 3, which is the ultimate product this paper. Each column of the instrument in Table 3 have been filled with the operational definition which is useful to assist interested school leaders and other educational stakeholders to adapt the instrument for the betterment of their respective organisation. 
Table 3: Operational Definitions for Measurement of School Climate Factors Using the Five Dimensions

\begin{tabular}{|c|c|c|c|c|c|c|c|c|c|}
\hline & \multirow{2}{*}{\multicolumn{2}{|c|}{ Aspect }} & \multicolumn{5}{|c|}{ Five Dimensions in Measuring Effectiveness } \\
\hline & & & & & Frequency & Focus & Stage & Differentiation & Quality \\
\hline \multirow{3}{*}{ 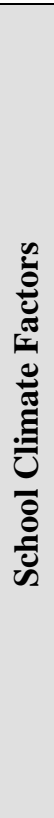 } & हैं & 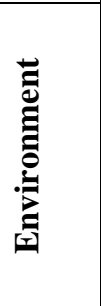 & 1 & $\begin{array}{l}\text { Provision of sufficient learning } \\
\text { resources to the students and } \\
\text { teachers (Provide more learning } \\
\text { opportunity for Ps and Ts - } \\
\text { Learning resources help Ts to } \\
\text { learn before teaching and thereby } \\
\text { become more effective in helping } \\
\text { Ps to learn) }\end{array}$ & $\begin{array}{l}\text { - The aspects covered } \\
\text { by the school policy } \\
\text { (examine the school } \\
\text { attempts to improve } \\
\text { educational } \\
\text { resources) }\end{array}$ & $\begin{array}{l}\text { - Specificity of the } \\
\text { policy/action } \\
\text { taken to improve } \\
\text { the school } \\
\text { learning } \\
\text { environment-in } \\
\text { relation to the } \\
\text { teaching and }\end{array}$ & $\begin{array}{l}\text { - The period the } \\
\text { policy/action is } \\
\text { established } \\
\text { - Flexibility - alter } \\
\text { from time to time in } \\
\text { relation to the } \\
\text { evaluation of the } \\
\text { school environment }\end{array}$ & $\begin{array}{l}\text { - Support is given to } \\
\text { Ts and Ps who are } \\
\text { resistant to and not } \\
\text { contributing to the } \\
\text { establishment of a } \\
\text { better learning } \\
\text { environment } \\
\text { - Different strategies }\end{array}$ & $\begin{array}{l}\text { - Policy/action-clear, } \\
\text { concrete and in line } \\
\text { with literature } \\
\text { - Support provided for Ts } \\
\text { and Ps to implement } \\
\text { the policy/action } \\
\text { - Improvement on school } \\
\text { climate factors based }\end{array}$ \\
\hline & \multirow{2}{*}{ 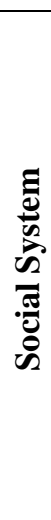 } & & 2 & $\begin{array}{l}\text { Collaboration and interaction } \\
\text { between teachers (establishing a } \\
\text { learning environment inside and } \\
\text { outside the classroom - learning } \\
\text { of Ts, effect on teaching practice } \\
\text { and thereby improve learning) }\end{array}$ & $\begin{array}{l}\text { (examine the school } \\
\text { attempts to facilitate } \\
\text { collaboration between } \\
\text { Ts - e.g. through } \\
\text { giving time and } \\
\text { creating opportunity } \\
\text { for them to work } \\
\text { together) }\end{array}$ & $\begin{array}{l}\text { learning of the } \\
\text { English } \\
\text { language }\end{array}$ & $\begin{array}{l}\text { to improve the } \\
\text { policy/action to } \\
\text { make learning of the } \\
\text { English language } \\
\text { more effective/better }\end{array}$ & $\begin{array}{l}\text { for different } \\
\text { personalities }(T s \\
\text { and } P S) \text { with } \\
\text { different values }\end{array}$ & $\begin{array}{l}\text { on evaluation or } \\
\text { subjective view of } \\
\text { stakeholders? }\end{array}$ \\
\hline & & & 3 & $\begin{array}{l}\text { Partnership Policy (i.e. relations } \\
\text { of school with community, } \\
\text { parents and advisor) }\end{array}$ & $\begin{array}{l}\text { (examine the school } \\
\text { attempts to establish } \\
\text { close relations with } \\
\text { the school community, } \\
\text { the parents and other } \\
\text { professional bodies) }\end{array}$ & & & & \\
\hline \multirow{2}{*}{ 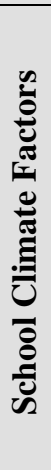 } & $\frac{2}{0}$ & 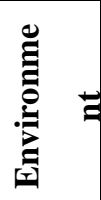 & 4 & $\begin{array}{l}\text { Pupil behaviour outside the } \\
\text { classroom } \\
\text { (establishing a safe learning } \\
\text { environment inside and outside } \\
\text { the classroom) }\end{array}$ & $\begin{array}{l}\text { (examine the school } \\
\text { attempts to create a } \\
\text { safe environment for } \\
\text { the Ps outside the } \\
\text { classroom) }\end{array}$ & \multirow{2}{*}{$\begin{array}{l}\text { - Specificity of the } \\
\text { policy/action } \\
\text { taken to improve } \\
\text { the school } \\
\text { learning } \\
\text { environment -in } \\
\text { relation to the } \\
\text { teaching and } \\
\text { learning of the } \\
\text { English language }\end{array}$} & \multirow{2}{*}{$\begin{array}{l}\text { The period the } \\
\text { policy/action is } \\
\text { established } \\
\text { - Flexibility - alter } \\
\text { from time to time in } \\
\text { relation to the } \\
\text { evaluation of the } \\
\text { school environment } \\
\text { to improve the } \\
\text { policy/action to } \\
\text { make learning of the } \\
\text { English language } \\
\text { more effective/better }\end{array}$} & \multirow{2}{*}{$\begin{array}{l}\text { - Support is given to } \\
\text { Ts and Ps who are } \\
\text { resistant to and not } \\
\text { contributing to the } \\
\text { establishment of a } \\
\text { better learning } \\
\text { environment } \\
\text { - Different strategies } \\
\text { for different } \\
\text { personalities (Ts } \\
\text { and Ps) with } \\
\text { different values }\end{array}$} & \multirow{2}{*}{$\begin{array}{l}\text { - Policy/action-clear, } \\
\text { concrete and in line } \\
\text { with literature } \\
\text { - Support provided for Ts } \\
\text { and Ps to implement } \\
\text { the policy/action } \\
\text { - Improvement on school } \\
\text { climate factors based } \\
\text { on evaluation or } \\
\text { subjective view of } \\
\text { stakeholders? }\end{array}$} \\
\hline & & 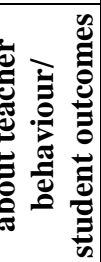 & 5 & $\begin{array}{l}\text { Value in favour of learning } \\
\text { (helping both Ts and Ps to have } \\
\text { +ve attitude to learn - to help } \\
\text { them to become more effective) }\end{array}$ & $\begin{array}{l}\text { (examine the school } \\
\text { attempts to develop } \\
+ \text { ve attitudes towards } \\
\text { learning on the part } \\
\text { of the school } \\
\text { stakeholders) }\end{array}$ & & & & \\
\hline
\end{tabular}

Source: Synthesized and adapted from "The Dynamics of Educational Effectiveness: A contribution to policy, practice and theory in contemporary schools" by B. P. M.

Creemers, \& L. Kyriakides, 2008, pp. 132-135

Copyright $\odot$ GLOBAL ACADEMIC EXCELLENCE (M)SDN BHD - All rights reserved 


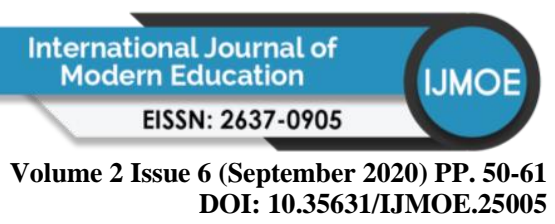

\section{Discussion and Conclusion}

DOI: 10.35631/IJMOE.25005

As mentioned in the first paragraph, this instrument is used by the researcher in the investigation of a low performing school in English at a rural primary school in Sabah. This instrument helps the researcher to gauge the site thoroughly without losing the focus of the investigation. The researcher is able to save valuable time in the investigation without missing important data. Apart from that, it provides a systematic basis for the researcher to synthesize the investigation more objectively and create a straightforward report for school to carry out relevant improvement programmes to improve the pupils' proficiency in the English language.

This instrument can also be used by other school leaders who are interested in self-evaluation in order to collect more holistic information in relation to the extent the influence of school climate factors on the teaching and learning of the English language. This may help schools to further understand the weaknesses as well as strengths of their schools. Nevertheless, the aspects in the instrument can be modified easily to mirror the essence possessed by their respective school before the instrument is administered.

The friendlier part of the instrument is that the concepts involved are generic in nature. Therefore, they can be applied across all subjects in schools. They also allow more "bottomup" initiatives to be put forth as the evidence gathered are empirically driven and grounded in nature. This is surely a plus point for the relevant authorities to obtain substantial evidence to plan programmes that can provide better impact on schools' future improvement.

In general, what Slater's and Teddlie's (as cited in Creemers \& Kyriakides, 2009) arguments that effective schools/leaders are expected to change in order to remain effective as their contexts change is well supported; school leaders must adapt their schooling to the changing context (p. 293). Educational leaders need to adopt, adapt, adjust to the conditions of the school if the school would like to procure better academic performance in the English language among the pupils.

However, improving the performance of English among the pupils is easier said than done. Improving the performance of English entails improving the instruction for English and this in turn entails improving the condition and environment of learning at the school level and that is what the researcher is experiencing while conducting this study. Henceforth, a systematic procedure should be established to collect valuable data before any improvement programmes can be carried out and this instrument is one of the ways to ensure comprehensive data gathering for more comprehensive analysis.

\section{Epilogue}

In the scenario of rural environment and low enrolment school, a vicious circle of low performing schools is very difficult to break without proper planning. Thus, low performing schools face even tougher challenge as the schools need not only to improve the performance of the subject but also to sustain the effectiveness in relation to the changing context of the school. Such predicament is supported by the Australian Government, Department of Education, Science and Training (2004) which reiterates the point, 


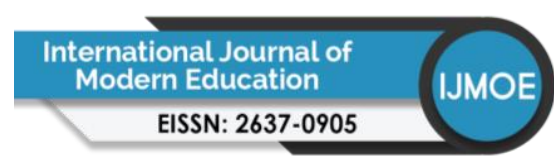

Volume 2 Issue 6 (September 2020) PP. 50-61

DOI: $10.35631 /$ IJMOE.25005

While research has shown that there are common characteristics of effective schools, it is important not to overgeneralise these observations. The presence of one or two of the characteristics is no guarantee of effective schooling. It is possible also that in one school one characteristic may be there to a greater or lesser degree than in others. The interaction between the factors is important because there is dependency between them... Policy makers need to know the extent and effect of these interactions (p. 8).

Researchers as outsiders can only 'open a path' for the insiders especially school administrators and teachers to follow up and follow through the research findings to ensure constant improvement to the school practices and learning environment.

This study has been a very meaningful journey and the researcher shall never look at a small rural school the same way again. It has opened our eyes about research too especially qualitative case study. It has been a daunting process for the researcher as it is a challenge but at the end of the day it will truly contribute something of substance to the world of education and research.

\section{References}

Anderson, C. S. (1982). The search for school climate: A review of the research. Review of Educational Research, 52(3), 368-420.

Australia Government, Department of Education, Science and Training (DEST) (2004). "Where to from here?". Schooling Issues Digest: School Effectiveness, 2004/1. Retrieved from http://www.dest.gov.au/NR/rdonlyres/5EE08C1D-E01F-4631820377EE83B47930/4020/ school_effectiveness.pdf

Brenner, M. E. (2006). Interviewing in the educational research. In J. L. Green, G. Camilli, \& P. B. Elmore (Eds.), Handbook of the complementary methods in educational research (pp. 357-370). Washington, DC: American Educational Research Association/Lawrence Erlbaum Associates, Inc. Publishers.

Creemers, B. P. M. (1994). The effective classroom. London: Cassell.

Creemers, B. P. M., \& Kyriakides, L. (2009). Situational effects of the school factors included in the dynamic model of educational effectiveness. South African Journal of Education, 29(3), 293-315. Retrieved from http://ajol.info/index.php/saje/article/ viewFile/45171/28661

Creemers, B. P. M., \& Kyriakides, L. (2008). The dynamics of educational effectiveness: a contribution to policy, practice and theory in contemporary schools. Oxon: Routledge.

Creemers, B. P. M., \& Reezigt, G. J. (1999). Chapter 2: The role of school and classroom climate in elementary school learning environment. In Freiberg, H. J. (Ed.), School climate: Measuring, improving and sustaining healthy learning environments (pp. 3047). London: Falmer Press.

Erickson, F. (2006). Definition and analysis of data from videotape: Some research procedures and their rationales. In J. L. Green, G. Camilli, \& P. B. Elmore (Eds.), Handbook of the complementary methods in educational research (pp. 177-191). Washington, DC: American Educational Research Association/Lawrence Erlbaum Associates, Inc. Publishers.

Gay, L. R., Mills, G. E., \& Airasian, P. (2009). Educational research: competencies for analysis and applications ( $9^{\text {th }}$ ed.). Upper Saddle River, NJ: Pearson Education.

Hesse-Biber, S. N., \& Leavy, P. (2006). The practice of qualitative research. Thousand Oaks, CA: Sage Publications.

Copyright $\odot$ GLOBAL ACADEMIC EXCELLENCE (M) SDN BHD - All rights reserved 
Kyriakides, L., Campbell, R. J., \& Gagatsis, A. (2000). The significance of classroom effect in primary schools: An application of Creemers' comprehensive model of educational effectiveness. School Effectiveness and School Improvement, 11(4), 501-529. doi:10.1076/sesi.11.4.501.3560

Kyriakides, L., Creemers, B., Antoniou, P., \& Demetriou, D. (2010). A synthesis of studies searching for school factors: Implications for theory and research. British Educational Research Journal, 36(5), 807-830. doi:10.1080/01411920903165603

Lim, B. S. H. (2018, October). The "3-D" Guiding Framework: Necessitating More Personalized Investigation and Measurement. Journal of Education and Social Sciences, 11(1), 10-18. ISSN 2289-9855. Retrieved from http://jesoc.com/issue/volume-11-october-2018-issue-1/

Merriam, S. (2009). Qualitative research: A guide to design and implementation. San Francisco, CA: Jossy-Bass/John Wiley \& Sons.

Teddlie, C. (1994). The integration of classroom and school process data in school effectiveness research. In D. Reynolds, B. P. M. Creemers, P. S. Nesselrodt, E. C. Schaffer, S. Stringfield, \& C. Teddlie (Eds.), Advances in school effectiveness research and practice (pp. 111-132). Oxford: Pergamon.

Tableman, B. (2004, December). Best practice briefs (No.31). University Outreach \& Engagement, Board of Trustees of Michigan State University. 